\title{
Herbert Quick's Hawkeye Trilogy
}

\section{A L L A N G. B O G U E}

In the barracks of the Red Cross at Vladivostock, the head of a commission to wind up that agency's work in the Far East lay close to death, his "heart missing on all the cylinders but one for lack of circulating medium." Feebly trying to put his affairs in order, he requested that an old Iowa friend be asked to complete a novel lying unfinished in his desk at home in Berkeley Springs, West Virginia. ${ }^{1}$ The year was 1920 and the man was John Herbert Quick. But Quick survived the hemorrhaging ulcer, returned to the United States, underwent surgery and completed the manuscript, later published as the novel Vandemark's Folly.

Herbert Quick was born in 1861 in a "little shanty" close to the border between Grundy and Hardin counties in Iowa and grew up on a farm in Grundy county. Somewhat crippled by polio at an early age, he became a school teacher in his teens and remained one until he gained admission to the Iowa bar after reading law for several years in the office of an attorney in Mason City. Then followed fifteen years of legal practice in Sioux City, beginning in 1890. During this period Quick energetically prosecuted boodlers and served for two years as the reform mayor of the city. But from an early age he had dreamed of being a writer: "I cannot remember when things that I saw and experienced did not appeal to me as the stuff of writing." 2 One of his close friends in Sioux City would recall Quick's habit of

Editor's Note: The title of the present essay has been supplied by the editor. Professor Bogue notes that the focus of his essay is on Vandemark's Folly and that he approaches Quick's work from the perspective of the historian rather than from the point of view of the literary critic.

1 Herbert Quick to Frederic F. Van de Water, April 28, 1924. A copy of this letter is to be found in the files of the Bobbs-Merrill Company in the Lilly Library, Indiana University, Bloomington, Indiana. This collection is cited hereafter as BMCP. Permission to quote from unpublished letters has kindly been granted by Herbert Quick's daughter, Mrs. Margaret Q. Ball.

2 Ibid. 
recording stories, expressions and phrases that he hoped to use in fiction. ${ }^{3}$ In 1901, at the age of forty, he published his first book, a volume of fairy tales for children. In the same year he submitted a poem to The Century Magazine about the prairie fires and nature life on the Iowa prairie that he had known as a boy; the editor accepted it with an encouraging note. These events confirmed Quick's appetite for writing, and after he had published Double Trouble, which he later called his "first really successful novel," he abandoned the law in 1905 and became a professional writer. Friends clucked, he recalled, and said, "Poor old Quick! The old simpleton will starve surely now! And he had a fairly good law practicel"4

Herbert Quick published eighteen books prior to his death, but journalism sustained him during the early years of his literary career. $\mathrm{He}$ had already written numerous stories for a Sioux City publication in behalf of the dry-farming movement, and in 1908 he became associate editor of La Follette's Weekly Magazine. The next year he became editor of Farm and Fireside, holding that position until 1916. During this period he established himself as one of the country's leading agricultural journalists and became a member of the "inner circle of writers" of the Saturday Evening Post. Meanwhile he contributed a stream of editorials to the daily press.

Herbert Quick was a progressive Democrat whose deep affection for the agricultural heritage of the country and whose conviction of the superiority of rural life did not blind him to the fact that there was much in rural America that was both unpleasant and inequitable. Deeply influenced as a young man by reading Progress and Poverty, he was convinced that Americans must fundamentally change their attitudes concerning the nation's natural resources and also adapt education to the particular needs of country folk. But at the same time he was an optimistic, practical man who understood the ways of politics and who could, himself, play the public relations man, lobbyist or politician. He once tried his hand at real estate promotion, on occasion ran for public office, and later prided himself on the fact that he had been in "the group that put the parcels post law through, and then the Federal Farm Loan Act." In 1916 President Wilson appointed him to a position on the Federal Farm Loan Board, and he spent three years helping to organize the great system of rural credit

3 Sioux City Tribune, October 21, 1925.

4 Herbert Quick to Frederic F. Van de Water, April 28, 1924. BMCP.

5 Herbert Quick to Edgar R. Harlan, September 26, 1924. Edgar R. Harlan Papers, Iowa Department of History and Archives, Des Moines, Iowa. Hereafter cited as ERHP. 
agencies, which was perhaps Progressivism's greatest contribution to meeting the unique needs of American farmers.

While Quick was serving as a member of the Federal Farm Loan Board he began the first of what he planned should be a series of novels depicting life in the nineteenth-century Iowa that he had known. These novels were not conceived on the spur of the moment. He later claimed that he had developed the basic concept and had begun to plan these novels before he was twenty and that he had described the project to one of his friends in the park in Indianapolis some fifteen years before the first of them, Vandemark's Folly, appeared. ${ }^{6}$ Quick regarded his work on the Federal Farm Loan Board in a sense as being war work, of the kind that a man of his age and physical condition could most usefully perform. But his duties took him from his writing, and when the war was over he resigned to devote full time to the Iowa novels, foregoing the salary of $\$ 10,000$ per year which the position would have brought to him during the remaining five years of his term of appointment. However, as Quick put it to a literary critic in 1924, he was "the worst hound pup you ever saw for following off false trails." 7 The Red Cross assignment intrigued him and almost cost him his life. After he had undergone surgery at the Mayo Clinic, the Iowa novels and his apple farm and country home in Berkeley Springs, West Virginia, were Quick's major concerns. Eventually he completed the novel which had languished in his desk during the Siberian adventure and also published its two companions, The Hawkeye and The Invisible Woman, although ill health continued to dog him, and his ulcer required surgery again in 1923 . He had completed the first segment of an autobiography when a heart attack ended his career, following an address that he delivered at a scholastic banquet at the University of Missouri in May, 1925.

While he was planning the Iowa novels, Herbert Quick visualized each of them to be part of a trilogy portraying Midwestern life in ever-widening perspective. He planned to call the first Vandemark Township, the second was to be Monterey County, and the third was to be simply entitled Iowa. In the first book he intended to describe the immigration to the new state of Iowa and the rural pioneering experience there during the 1850 's; the second would particularly

6 Herbert Quick to H. H. Howland, December 22, 1921. BMCP. Quick's autobiography, One Man's Life (Indianapolis, 1925), did not carry his story beyond the early prairie years, and he destroyed most of his correspondence. A number of the letters cited in this introduction are rich in autobiographical detail; of considerable interest also is Quick's article, "I Picked My Goal at Ten-Reached It at Sixty," American Magazine, XCIV (October, 1922), pp. 50-51, 161-164.

7 Herbert Quick to Frederic F. Van de Water, April 28, 1924. BMCP. 
describe county politics and life in the county seat; the concluding volume would picture state politics during the late nineteenth century. ${ }^{8}$ Although the original design had included but three Iowa novels, Quick began to plan a fourth novel, while at work on his autobiography, in which he intended to return to the Iowa farm life that he had used so successfully in Vandemark's Folly and The Hawkeye. Tentatively entitled Hell Slew, the fourth book was to be laid in the twentieth century and deal to some extent with the German-American settlement in Monterey County. ${ }^{9}$ Death blighted this project.

The serial rights to the first Iowa novel Quick sold to the Ladies' Home Journal. In negotiations which he then conducted with the Bobbs-Merrill Company for publication of the book, he described it and discussed its relation to the two that were to follow.

... this is the first of three novels which will cover the history of Iowa from its early settlement to recent times. The first which is finished, is the way things look and happened to a green boy settling in Iowa in the fifties. It is a cross section of the life of a boy born in southeastern New York in 1837 and takes in life on the Erie Canal, the factory life of the day, the things people thought and did, and the great flood of immigration into the Midwest. It sees only what a boy of that sort could see struggling with life, on the trail, and on the prairie farm. It has the lost prairie of Iowa in it. . . .

The three [novels] will constitute a single work and will be the story of Iowa and of the whole Middle West. It will be a sort of prose epic of the greatest thing in history of its kind. I lived this life, and am the only writing man who did. Garland did not live it, nor did Hough, though the former was born in Wisconsin, and the latter in Illinois [sic]. I was of the thing, as they were not. The story I have finished is a mingling of the life of my father. of my wife's father, of our relatives and neighbors.10

Although Quick was jealous of editorial changes to his book, he was apparently more reconciled to the editorial changes that magazine editors felt obliged to make. He allowed the editors of the Ladies' Home Journal to leave "all the guts out of the story" when they prepared it for serialization in 1921 and to change the title to Vandemark's Folly. When the editors of the Bobbs-Merrill Company also balked at using the title "Vandemark Township," he suggested the Journal's title as a satisfactory compromise."1 Similarly, the titles of the later books were also changed in deference to editorial criticism, somewhat obscuring Quick's original grand design.

Vandemark's Folly is the story of Jacobus Teunis Vandemark, who was born in Ulster County, New York, on Turnip Day, July 27, 1838.

\footnotetext{
8 Herbert Quick to H. H. Howland, April 26, 1921. BMCP.

9 Herbert Quick to H. H. Howland, February 2, 6, 1925. BMCP.

10 Herbert Quick to W. C. Bobbs, February 26, 1921. BMCP.

11 Herbert Quick to H. H. Howland, August 1, 1921. BMCP.
} 
When young Vandemark was only a few years old, his widowed mother took a second husband, the rascally patent-medicine salesman John Rucker, who abused both his wife and her son. He put the lad to work in a cotton mill at the age of six and made life a living hell for both mother and son, until the latter ran away at the age of thirteen to work on the Erie Canal under the command of a rough but goodhearted canal boat captain. When he returned to his home after some months, the youngster discovered that Rucker had taken his mother to the West. For several years young Vandemark worked on the canal and for the family of the captain who had befriended him, but in 1854 he discovered a clue to his mother's whereabouts and tracked her west to Madison, Wisconsin. There he discovered that she had recently died, and Rucker tried to satisfy the son's claim to her estate by deeding him a section of land in lowa and outfitting him with a team of horses, wagon and supplies so that he could journey to the frontier and settle on his land.

On the trail Young Vandemark traded his horses for cows and those in turn for additional sore-footed animals, so that when he arrived in Monterey County he was the owner of a considerable herd of cattle as well as the nickname "Cow." During the trip he also encountered various individuals whose destinies were to intertwine with his, but none of Vandemark's actions was to be more fateful than his decision to give shelter to Virginia Royall, who was trying to escape the advances of her womanizing brother-in-law, Buckner Gowdy, a wealthy Kentuckian who was on his way to develop a large holding in Monterey County. When the young people arrived in Monterey County, Vandemark delivered Virginia into the hands of the local clergyman's wife and discovered that the land surrendered by his foster father was in reality Hell Slew, an intimidating marsh, soon derisively renamed Vandemark's Folly.

After this crisis, Jacobus T. Vandemark settled into the task of developing a farm, trading labor and pioneering skill with his Norwegian neighbor, Magnus Thorkelson. The book describes Jake's rather diffident courtship of Virginia Royall and Buck Gowdy's seduction of the beautiful but naive Rowena Fewkes, who was saved from a life of shame when Magnus Thorkelson married her after she gave birth to Gowdy's child in Jake's cabin. Intermingled with these developments are the theft of the county funds, the activity of the local claim club, a prairie fire and other incidents of pioneer life in central Iowa. After serving briefly with the men of Monterey County in the Civil War, young Jake Vandemark finally trounced Buck Gowdy and saved Virginia Royall, now the local school teacher, from a first-rate Iowa 
blizzard by seeking shelter in a straw stack, where he found the courage to propose. Not only had Jake Vandemark won the most desirable young woman in Monterey County-time and the ditching dredge would show that Hell Slew, like so much of the wet-land prairie, was fantastically fertile farm land. Looking back on these events in the final chapter of Vandemark's Folly, Uncle Jake Vandemark had ample grounds for believing that he had been a most fortunate man.

Herbert Quick undoubtedly believed that he had dealt successfully with a great theme, but it also seems clear that the enthusiasm which he expressed in his letters to the Bobbs-Merrill staff may in part have reflected his desire to spur them to more active advertising of the book and the companion novels which were to come later. Quick refused to allow the editors to claim that this was the best American novel ever written, but he was willing to allow them to publicize the fact that he had refused to allow them to make that claim. He wrote to Hewitt H. Howland of the Bobbs-Merrill Company:

Really the story is a better treatment of The Growth of the Soil than Hamsun's book for which he got the Nobel prize this year. It is the inside story of the greatest epoch in American history and the growth of the soil. And while we had some immoralities and departures from the Commandments as I show, I am glad to say that veritism itself could not reduce the settlement of our soil to the dead level of sordidness shown in the Norwegian tale. And we did it on a great scale, and not by carrying burdens on the back as Hamsun's Isak did. The difference between the settlement of our Midwest and the newer parts of Norway is just the difference between Jake Vandemark with his train of cows, and Isak with his burdens on his back and his pair of goats, and Jacob's nice wife and the irregular relations between Isak and his woman. . . .12

In the margin of this letter Quick pencilled the word "Conceit" and added the word, "No." Yet the need of advertising copy was perhaps in Quick's mind because he ended the letter with, "Anything in this?" Later he was to comment on the "simplicity and elemental character which is the great charm of Vandemark for many readers." 13 When an Iowa lady complained that there was too much sex in the book for readers of school age, Quick defended himself:

I think the book will be read all through the future as having significance as to the moral, political, sociological, and historical development of America. I want the readers, whether they are in school or out of it, to know what boys were allowed to do and see on the Erie and the other canals of that date. I want them to know what sort of people carried on the great and necessary work of transportation, which saved the Union when it tended to

12 Herbert Quick to H. H. Howland, September 10, 1921. BMCP.

13 Herbert Quick to H. H. Howland, July 2, 1922. BMCP. 
break at the end of transportation lines. I want them to know how the people of the United States allowed their little children to work themselves to death in the factories of that period. So I use actual occurrences which I have obtained from actual participants-as the basis of my novel. I am glad to have been able to find them. My only regret lies in my inability to use them as well as they might have been used. But I would not gloss one of them over. 14

In general, reviewers greeted Vandemark's Folly with praise; some even discovered in it qualities essential to that unachieved masterpiece, "the great American novel."15 When The Hawkeye appeared in the next year, it apparently benefited from the favorable reception of Vandemark's Folly, and it in turn found new readers for the first book. Visiting Iowa to promote Vandemark's Folly, Quick found himself "lionized to an embarrassing degree," both in Iowa and Missouri, and a favorite pastime of those whose memories extended into the nineteenth century was the effort to match the names of actual Iowans with Quick's characters. Benjamin Shambaugh of the Department of Political Science at the State University of Iowa, and Director of the State Historical Society, delighted Quick by repeating his conversation about Vandemark's Folly with Samuel Sloan, the English Department's specialist on the novel. Said Shambaugh, "I don't know anything about novels but as history this is a great and an accurate book." Replied Sloan, "I don't know anything about history but as a novel it is a great book." 16

The Nation's "roving critic," Carl Van Doren, wrote one of the more unfavorable reviews of Vandemark's Folly. To Van Doren the book was a throwback to the historical romances of twenty years earlier, and Jacob Vandemark was drawn "very much in the manner of" Winston Churchill's David Ritchie. Both heroes, argues Van Doren, were unfortunately constrained in the romantic convention that descended from Lorna Doone's ponderous hero, John Ridd. It was a pity, Van Doren suggested, because the westward movement was a great theme. Although he commended the research, liked some of the minor characters and found the style "free and charming," he argued that

to see wherein ... [Vandemark's Folly] falls short of some of the greatness with which it is credited, one has only to think of any of the better Icelandic sagas. The parallel is exact. The sagas, set down with scrupulous exactness or with the look of scrupulous exactness, are the records of certain settlers who went from an older country to a newer. They, unlike Vandemark's Folly with its romantic conventions, keep their eyes forever on the immediate

14 Herbert Quick to D. L. Chambers, March 3, 1922. BMCP.

15 See for instance The New York Times Book Review (December 7, 1924 ), p. 8.

16 Herbert Quick to H. H. Howland, May 30, 1922. BMCP. 
facts of life as their writers understand them. They know how to represent heroic deeds by letting the deeds speak for themselves. . . 17

Although he clearly distinguished between the role of the novelist and the job of the historian, Herbert Quick apparently believed that in this instance the critics should have asked the questions: "Are Cow Vandemark and his fellow characters believable? Could the events in which they participated really have happened?" And to these queries the author would have replied: "This man and his relatives, friends and enemies did indeed live in frontier Iowa; they did the things described in the book." The benevolent glow that suffused Uncle Jake's narrative is to be found again and again in the stories of early settlers in the county "mug" books and in the statements of the pioneers in the transactions of the Old Settlers Associations. Scattered through the lines of Vandemark's Folly is a generous offering of the vernacular idiom of the Midwestern frontier. If Buck Gowdy seems a somewhat melodramatic villain, we can remember that some Iowans did indeed own broad holdings in the pioneer period, that some Iowans did indeed drive their horses hard, that some Iowans did indeed pursue women with ruthless enthusiasm. It is not too much to believe that one individual did all three. The verdict of the literary historian, however, has been that Quick's Iowa novels are not literary masterpieces, that as novels they fall short of Willa Cather's stories of pioneer life in the Middle West. At the time, Quick apparently regarded Hamlin Garland and Emerson Hough as his major rivals in interpreting the Midwestern experience.

For the historian, the discursiveness which some critics regretted in Vandemark's Folly is an asset because in part it portrays the detail and color of the pioneering era. Although Quick loved to write fiction more than factual articles, he had the journalist's fetish for accuracy. In some earlier novels he had tried to convey an ideological message; in the books of the Hawkeye trilogy he was trying to tell good stories but he was also trying to describe the natural environment and to write the early social history of the prairie heartland. He makes a great deal of this point in the letters which he wrote about Vandemark's Folly. He emphasized the research that he had put into the novel, and we know that he borrowed books from the Iowa State Historical Society and read Iowa newspapers at the Library of Congress

17 Carl Van Doren, “The Roving Critic," The Nation, CXIV (March 15, 1922), p. 319. 
while preparing the last two volumes of the trilogy. ${ }^{18}$ Of Vandemark he wrote,

The life in New York and along the canal in the earlier portions of the book is historically accurate. My father and my mother and my grandparents, and my wife's parents and grandparents lived in York state during these years. I got the cotton-mill facts from an old man who knew from having worked in the mills. He was eighty-five years old. The canal life is from a hired man who used to come to Iowa and work in the harvest field with me on my father's Iowa farm year after year, and talked all the time of life on the canal. But in order to know exactly the mental atmosphere I studied the period as if I were going to write a history of canals in America.19

He admitted that the characters in the book were modeled on Iowans of his acquaintance and was somewhat embarrassed when one reader correctly identified Coker F. "Father" Clarkson of an eminent Iowa political family. There are few, if any, better descriptions of the prairie in American literature than those in Vandemark's Folly; they sprang from Quick's recollections of the days when he and his brother picked up the eggs of prairie chickens by the hundred and when prairie fires ran unchecked from the Cedar River to the Iowa.

We cannot argue, of course, that Quick's research was as thorough as that of the historian should be or that he was trying to do more than present a generalized picture of western immigration and prairie settlement. But the social structure, the institutional fabric and many of the local events that he described in Vandemark's Folly rang true. Arthur M. Schlesinger believed that the novel revealed a "historian's viewpoint" in its author and, according to Quick, invited him to contribute one volume to the twelve-volume history of civilization in America that the historian was planning. ${ }^{20}$

Had Quick's reading included "The Significance of the Frontier in American History"? Certainly that seminal essay may have influenced Quick, although its basic ideas are in part to be found in Progress and Poverty, which Quick had read before Frederick Jackson Turner presented his famous paper. But the idea that the frontier settlers were in a primitive state of "precivilization" is found in Quick's writing. ${ }^{21}$ On the other hand, he was sure that the prairie frontier was a unique frontier where the pioneers first met and solved the challenge of the

18 Herbert Quick to H. H. Howland, July 2, 1922, BMCP; The Des Moines Tribune (May 11, 1925).

19 Herbert Quick to H. H. Howland, December 22, 1921. BMCP.

20 Herbert Quick to H. H. Howland, February 9, 1923. BMCP.

21 Herbert Quick to Edgar R. Harlan, September 26, 1924. ERHP. 
grasslands. ${ }^{22}$ After The Hawkeye appeared, Quick sent a gift copy to Turner, whom he incorrectly identified to his editor at first as being at Yale. Alas, the historian's letter of response, though comforting, could not be converted to advertising that would sell copies to the "hoipolloi." 23 Turner's version of the frontier hypothesis does not seem to have been a major influence in shaping Quick's ideas.

Vandemark's Folly sold well for the period, but not spectacularly. Appearing early in 1922, it advanced to tenth place on one list of best sellers during the spring of 1922 , but it did not become a best seller in the usual meaning of that phrase. ${ }^{24}$ Correspondence between Quick and officers of the Bobbs-Merrill Company revealed some disappointment at sales during 1922.25 Quick ultimately hinted that the publisher's advertising campaign had been ineffective. ${ }^{26}$ The BobbsMerrill Company sold reprint rights to A. L. Burt and Company for a popular edition that appeared in 1924. In 1939 Grosset and Dunlap obtained reprint rights to both Vandemark's Folly and The Hawkeye. Details concerning these later printings are apparently unavailable. At least one Iowa newspaper arranged to serialize Vandemark's Folly in its columns during the early 1930 s. $^{27}$ One of the officers of the BobbsMerrill Company wrote in January of 1922, "I rather imagine that we have in Vandemark's Folly the real epic of the development of Iowa," but the faithfulness with which Quick had depicted the Iowa story may have detracted from the general appeal of the book. ${ }^{28}$

Between 1940 and the late 1960s Herbert Quick found few admirers among specialists in American literature. Recently, however, scholars in this field have testified to enduring merits in his work. ${ }^{29}$

22 Herbert Quick to Edgar R. Harlan, May 2, 1925. ERHP.

23 Herbert Quick to H. H. Howland, July 1, 1923; Quick to D. L. Chambers, August 11, 1923. BMCP.

24 The leading authority on Herbert Quick's fiction, Professor Carl L. Keen of Oshkosh State University, believes that the Bobbs-Merrill Company sold 75,000 copies of the book during the first few months after publication. A royalty statement among the August, 1922, letters in the Quick Collection in the company files in the Lilly Library suggests a sale of 27,500 copies through the first half of 1922. In a letter to this writer of July 7, 1969, Miss Lois Stewart of the BobbsMerrill Company reported that the company "print-and-bind" records show a printing of 34,000 copies.

25 Herbert Quick to D. L. Chambers, April 21, 1922. BMCP.

26 Barton W. Curry to Herbert Quick, September 23, 1922. BMCP.

27 See The Des Moines Tribune Capital (October 20, 1931).

28 D. L. Chambers to Edgar R. Harlan, January 30, 1922. ERHP.

29 Roy W. Meyer, The Middle Western Farm Novel in the Twentieth Century (Lincoln, 1965), pp. 47-56; Carl Lee Keen, “The Fictional Writings of Herbert Quick" (Doctoral dissertation, Michigan State University, East Lansing, Michigan, 
One of them, Professor Carl L. Keen, has suggested in addition that the Iowa trilogy is an outstanding illustration of the Adamic myth in American fiction, in which Cow Vandemark represents the unfallen Adam. ${ }^{30}$ To the historian, however, Vandemark's Folly is valuable because it faithfully depicts one chapter in the epic of a nation moving westward. If the book is, in reality, only "near history," few historians have been able to match its perceptive portrayal of the pioneer experience.

1967); and Frederick Garver Morain, "Herbert Quick, Iowa Agrarian" (Doctoral dissertation, Yale University, New Haven, Connecticut, 1970).

30 Carl Lee Keen, "Fictional Writings of Herbert Quick," Abstract, p. 3. See also page 132 for another general interpretation of the place of Vandemark's Folly in the trilogy. 

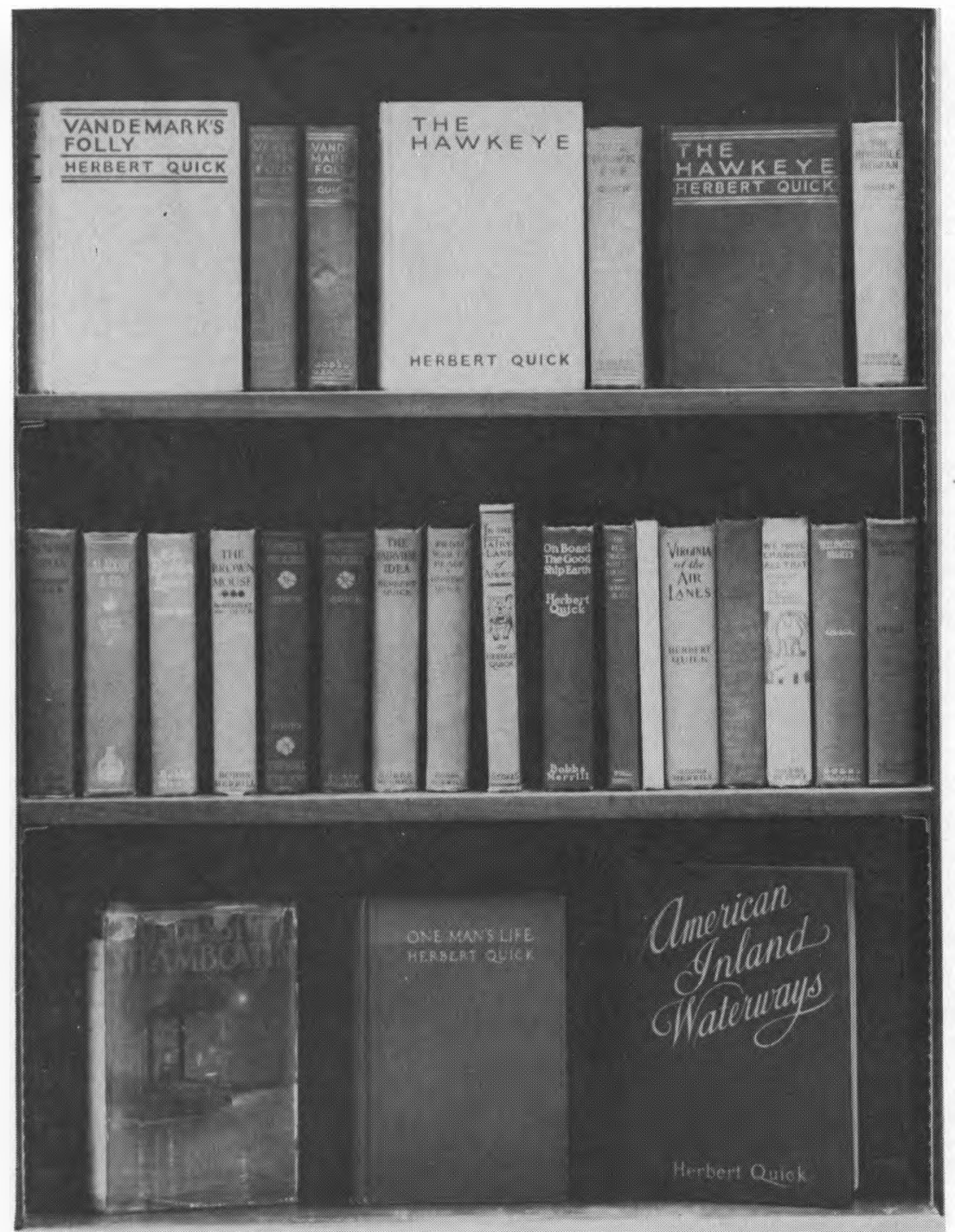

Books by Herbert Quick in the Iowa Authors Collection. Shown on the top shelf are first and later editions of Quick's "Hawkeye" trilogy-Vandemark's Folly (1922). The Haukeye (1923) and The Invisible Woman (1924). Lacking is a copy of the paperbound Armed Services edition of The Hawkeye (ca. 1944). Can any of our readers supply this desideratum? 